\title{
The Graduate Law Degree Holders in the Legal Education Market: Evidence from the US, Rankings and Implications
}

\author{
Kiyoung Kim, Shahin Borhanian, Koo-Tae Chung, Yong-Hyun Park, Won-Sang Lee, Jae-Hyung Kim \\ Department of Law, Chosun University, Gwang-ju, South Korea \\ Email: kiyoungkim@chosun.ac.kr,hsi1844@chosun.ac.kr,ktchung@chosun.ac.kr, yhapark@chosun.ac.kr, \\ alpiuris@chosun.ac.kr,jhckim@chosun.ac.kr
}

How to cite this paper: Kim, K., Borhanian, S., Chung, K.-T., Park, Y.-H., Lee, W.-S., \& Kim, J.-H. (2016). The Graduate Law Degree Holders in the Legal Education Market: Evidence from the US, Rankings and Implications. Beijing Law Review, 7, 371-399.

http://dx.doi.org/10.4236/blr.2016.74031

Received: October 5, 2016

Accepted: December 26, 2016

Published: December 29, 2016

Copyright $\odot 2016$ by authors and Scientific Research Publishing Inc. This work is licensed under the Creative Commons Attribution International License (CC BY 4.0).

http://creativecommons.org/licenses/by/4.0/

\begin{abstract}
Given that the law is helpful, essential and non-separable with our lives, we surely would like to know the people that make laws and who practice in the legal profession. This query is the recent theme we have pursued in this and other related projects. The investigation has revealed a knowledge economy (savoir-faire) that has entwined law and the actions of law people, which growingly became edged to explain their behavior and moral and professional conduct. The expectation has been that graduate law classes are for foreign lawyers who would return to their home country to work as international lawyers or as professors. That has long been deemed as a given; but the precise reality has not been previously unraveled. With this backdrop, the current paper purports to survey the status and performance of graduate law degree holders in US law school, to rank global law schools, and explore the implications and findings concerning the processes and outcomes of their missions.
\end{abstract}

\section{Keywords}

Law School, Legal Education, Research Impact, Faculty Recruitment, Educational Rankings, Academic Degree

\section{Introduction}

Would a lawyer be the worst of neighbors? There is a traditional Korean proverb that says just that. Nevertheless, the profession is thought by some to be one of the oldest on earth, perhaps comparable in antiquity with priests, monks or emperors ${ }^{1}$.

${ }^{1}$ It is sad, nevertheless, if the Empire of Law, as dreamed by R. Dworkin, is not perfect within the international community. The theme, "taking rights seriously", simply diverges from the political or public life although it evinced the epitome of legal academia. 
The practical use of laws also has had plenty of modern examples: We can ask for civil damages in case of an unfortunate traffic accident or seek recourse in case of an unexpected termination of pension benefits without due process of law. If aggrieved by unjust layoffs, we are entitled to fight for our rights with the assistance of a lawyer. Most importantly, many of us are beneficiaries of a democratically engendered legal process that helps to maintain our civilized lives with fundamental rights to protect life, limb and property being duly proclaimed and sustained by the polity or nation. The psychological benefits, alone, from a stable system of law, should be immeasurable if we take into consideration the resulting freedom from constant fear of non-predictable others. The kind of Hobbesian imagination of chaos if unchecked would be neither so radical nor remote if we see the turmoil of lawless communities in the movies or in a TV scene (Sherman \& Cohn, 1989). The zombie ghosts from a contagious death-as depicted in violent scenes in a recent Korean film, titled "Train to Pusan"-would not be irrelevant to an imagination of real life lawlessness of humans living in an uncontrolled community. Since the current form of modern democracy and free market capitalism has been founded, legal professionals have turned out to be one of the most important societal groups to sustain it. Lawyers have always been politically involved and their job is the most probable to help lead the nations. While many lawyers have been inculcated with the values of revolutionary ideals, the greatest of them have even been destined to proclaim the vision of supreme national documents. Given that the law is helpful, essential and non-separable with our lives, we surely would like to know the people that make laws and who practice in the legal profession and are responsible for the authority and prestige of law professionals (Glendon, Gordon, \& Osakwe, 1994; Pistor, Wellons, \& Sachs, 1999). This query is the recent theme we have pursued in this and other related projects.

As background, this research planned to address the trending diversity of global education and law disciplines with increasing attention to ubiquitous socio-cultural terms that characterize the personalities and thoughts that trend in the traditional economic or political world. This study purports to elucidate a grey area of legal education that generally has been neglected out of the main concern of legal educators. Its focus on professionalization or graduate level education is also correlated with the fast changing intensity and diversity of market demand or knowledge economy. The taught-based doctorate, what we know as JDs in US law schools, would perhaps be more unique, and educational reform to crown the professionals with further graduate level degrees will seemingly continue to respond to new market demand. Executive MBAs or a different form of Doctor of Education than the traditional $\mathrm{PhD}$ in education may be one outcome to approximate JDs in law school. The sorting or ranking of graduate law degree holders, in this respect, can assist with a more refined understanding and could be a seminal work for spectators and interest holders of the legal education market, including graduate law students themselves, law teachers, investors and policy makers in this area (Korobkin, 1998). The traditional ranking sources dealing with law schools are fortunately diverse or more specific given the relatively popular at- 
traction of the legal market, more so than that of other departments. The National Jurist, Brian Leiter's and many other student guides actually produced meet these kinds of needs. They lack, however, a serious inquiry into the arena of graduate law degree holders. To address this gap, we have collected data and evidence to assess the status and performance of LLMs and SJDs within the US law teaching market and analyzed them, ranking graduate law degree programs to appreciate the nature and quality of graduate law education. We also hope this research can fulfill a pioneering role to motivate further research. In Section 2, we will briefly state the problem leading to this research, the purpose of research, and how it was conducted. Though it is a comprehensive survey, the research has some limitations that are briefed in Section 3. In Section 4, we will present the analysis of data and implications of analyzed results. A short conclusion will follow in Section 5.

\section{Background of This Study}

\subsection{Problem}

Who is it that leads and shapes the important institutions and groups of people that are involved in the legal profession? More specifically to suit the purpose of this research, who is in charge of developing their important frame of reference and the legal research that not only sustains the law schools, but also shapes legal education and the real world of law practice? One aspect of the answer to this question requires that we survey the educational background of law professors and legal practitioners and rate their performance (Laband, 1986; Masuoka, Grofman, \& Feld, 2007; McCormick \& Bernick, 1982; Schmidt \& Chingos, 2007) ${ }^{2}$. Interestingly within the US legal education system, we can find a dual class of degrees, JDs and graduate law ones, including those we denote as LLM, SJD or PhD in law. We have commonly in mind that legal education produces jurists, and law schools have long been held of import to the process of creating JDs, who would be deemed to be the majority in number and the foremost in providing professional legal services (Amsterdam, 1984; Wizner, 2001). The presumption is that the holders of this degree would become law professors, federal or state judges, state attorneys, and conduct the practice of law in large or medium size firms or in small firms or in the solo form. The expectation has been that graduate law classes would be for foreign lawyers and that they would return to their home countries to serve as international lawyers or professors. That has long been deemed as an undeniable given, but the precise reality has yet to be unraveled. Since the ranking of certain things in this inquiry would be an important beginning point to appreciate their nature and quality, we resolved to survey the reality of the above assumption to yield a ranking which hopefully could develop through further research concerning the students who attend graduate law schools and the outcome of their studies (Brian Leiter's 2016; Brophy,

${ }^{2}$ Often the rankers tend to maintain a focus on the performance of faculty or credentials of admitted student, and other temporary variables. In comparison, the degree-based and all-time approach could be vested and durable in view of assessing and generating a ranking. Given the use of ranking sources, the approach can also have a strength to guide prospective students and investors, who essentially have to be have a long-term view of years or decades in life management. 


\subsection{Purpose and Method}

In this backdrop, the purpose of this research, firstly, is to assess the statistics and performance of LLMs, SJDs and PhD in laws within US law schools. Secondly, it will rank graduate law programs across those degrees to help the audience and interested players appreciate the nature and quality of the professionals with those training backgrounds. In order to address the purpose, we employed a quantitative method that investigated the whole of all of the US law school websites identified according to their ranking in US News and World Report (USWR) ${ }^{3}$. Often quantitative researchers use public surveys with samples and scaled questionnaires (Creswell, 2013). However, such methodology would be less than relevant to the purpose since the theme does not pertain to the psychological or social perspectives. Therefore, the method of this study is similar to the national census for demographics, and this paper deals with the overall parameters relevant to our interest. Viewed globally, the research can be considered to deal with the most prominent cluster of relevant examples, namely, US law schools in some level of global prestige. The lead author of this paper had previously published the consulting-based SJD ranking (on fixed scale with 15/15/15/55), which was created from the Shapiro's and truly global since it was compiled on the basis of Hein Online and ISI (Kim, Ju, \& Khatun, 2015). The investigation in this paper, on the other hand, is based on US law schools, but could be translated as global since the professionals are highly mobile to build their career paths. Also, the LLM program is a short year course, whose holders are more than widespread through the scope of the search and significantly internationalized. The SJD degree costs the students more years to complete hence possibly less internationalized-but it still is not irrelevant since many holders are from the international context. The point is that the LLMs, SJDs or PhDs in law across the globe can be taken equal and analogous to those that pursue the law teaching market in the US in furtherance of their legal career. Therefore, the result can be read within the national context of US legal education on one hand, and could be viewed globally on the other or taken as the kind of ideal, "perfect market" conceived by Adam Smith".

\footnotetext{
${ }^{3}$ One law school around a middle-low rank had a concise website without the educational background of professors and the website of another law school in Puerto Rico was defunct and could not be retrieved. Therefore, two law schools were unfeasible to investigate, which, however, is negligible in effect.

${ }^{4}$ According to our experience, the international rankers, such as QS, ARWU, THE, began their commitment on the assumption that the market of knowledge economy or university institution can be idealized and universal despite local contingencies-such as language or culture and other provincial impacts on the system. Hence the basic assumption is objectivized as supported by the perfect market thesis of Adam Smith. The idea may be married with globalization or neo-liberalization as a virtue of global capitalism, which has been a principle for decades, but with the inevitable resistance, adjustment and transformation. Many may agree that the thesis of "glocalization (global + local)" is better received more realistic and practical for the citizens of global village. In terms of the educational aspect, the regional ranking of QS and use of regional reputation by USWR for the ranking of global universities could be seen as one kind of adjustment or transformation. The paper begins to accept the reasoning of this theoretical phenomenon, but with a care for the growing conservative ethos of nationalism or conservative ideals in the world of real politics. Practically-we mean by this to be in comparison with the ideal or statistical assumption abovementioned-and results can be taken as global to see who is more cognizant or is more scholarly in the US law than others among global LLMs or research doctorates in law.
} 
The investigation had been performed roughly two months this summer along with the assistance of research aides. 10 or 20 law school websites were analyzed on a daily basis except for a recess period of one week to allow for attending the international schedule arranged during the last days of July, 2016. Since our focus had been on the research impact of law professors, and to avoid undue expense in time and energy, the faculty labelled "clinical", "visiting”, “adjunct" and "other classes" less relevant to the role of devoted research was discarded. Since their product and citations are often minimal, new law professors, labelled "lecturer" and "assistant professor" were also excluded out of the investigatory scope. Therefore, the data that captured the purpose was such that covered those, who were designated with the title of "associate professor of law", "professor of law" and "emeritus (APEs)". We reasonably assumed that they would comprise the core of the people whose statistics would show the contemporary reality of professional research in the US law schools. As appears in the Table A1 of Appendix, the number of faculty per graduate had been made one component of four variables in the final ranking that the lecturers or assistant professors may be partly implicating. The assumption, however, is that the APEs could be proportional of new faculty recruitment. Contemporary raters popularly focus on the number of publications and citations, which often are converted into per capita productivity. This perspective basically guided the aura and direction of the paper's methodology. Therefore, the ranking is essentially per capita, except for the total of citations, which, we believe, helps to see the whole picture of interest. This allows one to also use the number of faculty as an indication of publications given that the average law professor yielded $2-4$ articles or books yearly.

\section{Limitations of Study}

This investigation relies upon the scholarly works available on the Internet depository at "scholar.google.com (SGC)" or publicly open records in accordance with the best available evidence principle. While the concept of research impact is equivalent to that of Shapiro and is based on citations or the recently coined term, citology, the standard of quality obviously came out different, and is admittedly rough and less than ideally defined. A strict dividing line to preserve the distinct identity of legal science held faithfully by Shapiro was necessarily sacrificed due to the counting of the whole of the available data (Shapiro, 2000, 2012) $)^{5}$. Therefore, the citations of staff papers, unpublished SSRN materials and monographs or even informal writings as well as products or citations by non-legal sources were included (Black \& Caron, 2006). For similar reasons, Joseph Raz and John Finnis-British educated legal scholars-had far more counts than that of the Shapiro's article published in 2000. Nevertheless, Shapiro's care to comply with the "less than half rule" for identification of the "legal scholars" as opposed to those of "social science" has been maintained since merging the social and legal science data would likely produce an egregious result. Such confounded data would

${ }^{5}$ This way of dealing, therefore, is close to the approach of Webometrics that ranks global scholars and institutions. 
efface the identity of the legal education system as a whole (Shapiro, 2000, 2012). For this reason, Max Weber, a doctorate in law from Germany-if assumed as an emeritus professor in US law schools-has been excluded although he should have been counted based on the Hein Online or law-related ISI data ${ }^{6}$. This same rationale has been applied to exclude B.S. Santos, who is a graduate law from Yale and currently has a post at UW-Madison law school. In this respect, the refinement of the classification by Shapiro, distinguishing such categories as law review articles, legal books, text writers, non-legal materials or method to determine the standard of law journals had a very good and vital cause. Generally, his method is crucial to preserve the identity of law, legal science, and the law school system, and we have partly and to the extent possible adhered to it through the work-and deviated from it, however, only to broadly sketch the area of contemporary exposure (Priest, 1983) ${ }^{7}$.

It was also not possible to strictly filter the citations to reduce the numbers counted multiple times although they were made by one article, and the counts were made to reflect maximum totals ${ }^{8}$. The accuracy of counts, however, was attended to the best of human effort. Nevertheless, it was true that we faced some difficulties when the authors did not have an author page on Google Scholar'. Therefore, a margin of error in counts might be present, but it is believed that the efficacy of the final ranking will not be affected.

Since there are a number of law-related graduate law degrees, identifying them is not so simple, and they could have variant titles and distinct characteristics according to their program purpose. The MLS degree of Yale or Illinois and MLI of Wisconsin ${ }^{10}$ are examples of degrees that serve the need of legal study by scholars of other disciplinary backgrounds or whose principal purpose is more to teach the basics of US laws to prepare participants for the LLM or SJD courses than it is to deepen legal knowledge. With this understanding, we have discarded the professors of those degrees who do not also hold traditional master of law degrees. One problem is that although the MAs, MPhils and diplomas from British or European institutions may well be no less significant, their confirmation was impossible unless the information best available, such as a resume of each professor, specified the same as comparable to an LLM or traditional master of law degree. Those professors as vague or impossible to confirm degrees have,

${ }^{6}$ In this interest, you also can refer to the system of ranking law journals, for example, the website of Washington and Lee University Law School.

${ }^{7}$ For example, if the applicability of "less than half rule" is ambiguous because of close number, the citation count had been adjusted to portray the most proximate result for the impact of legal education.

${ }^{8}$ Therefore, the way differs from any popular standard to count the cites, say, "one count per paper than one count to cites."

${ }^{9}$ As we see in the Webometrics ranking, the personal or institutional account and webpage in the SGC is highly implicating for the performance of global scholars. The scholars from other disciplines, often with more than citations, tend to manage it, which is significantly less relating with the law professors. This means that most of counts had been hand-on carried, which consumed much time for accuracy and verification. It also implies the hybrid nature of law school or legal education as professional, while the legal science stands at the centre of knowledge economy along the growing economy and technology advancement.

${ }^{10}$ It was recently changed of name for the LLM-Legal Institution, but considered to be excluded because of the same characteristics as before and, more importantly, no relevance to this study scope for the change's recentness. 
therefore, been foregone without consideration. On the other hand, LLM programs are becoming more specialized to focus on topics of public interest or other special legal merit. Most notably, the LLM in taxations offered by NYU impacted much on the jurisprudence, and the environmental law program by Vermont notwithstanding its degree-based impact had a stark presence as a successful example of specialization ${ }^{11}$. In some cases, even the SJD program is trending toward specialization as we see in the Pace University's program for environmental law, Case Western's program for health law and University of Florida's SJD for taxation ${ }^{12}$. The graduate law programs are diverse according to the context of each school and display varying gross size differences. The size of each graduating class was confirmed to the best of available evidence, for which the LLM Guide of World Universities was an invaluable help. The chatting space of interested students as well as each school's website also served as a source of verification about the LLM class size. The final number has been adjusted by adding five to six SJD admissions, which is reflected in the whole size of the graduate law programs. Information from students and other interested actors was thought to be crucial to know the nature and quality of these programs. Across the webpages of alumni chatrooms, the LLMs seemingly had many interests about the admission policy and statistics of the programs, while the SJDs emphasized their scholarly experience along with the general prestige of law schools ${ }^{13}$. Besides the generalized law school rankings, a more focused ranking on LLM program was available as assessed by the American Universities Admission Program (AUAP) ${ }^{14}$. My previous study on the consulting based-ranking of SJD program also could be referenced in this respect (Kim, Ju, \& Khatun, 2015).

\footnotetext{
${ }^{11}$ Years recently, Dean of Vermont law school had a chance to visit South Korea, and remarked very proudly that an eager student of environmental law had dropped his admission to the JD program of Yale law school, and decided to accept the offer of Vermont. It implies that the research quality of law schools can affect not only graduate law students, but also the JD applicants.

${ }^{12}$ The SJD students are very few and a few law schools had offered the program as the website from the Lewis and Clark introduced, "Very few U.S. law schools offer this degree, and very few people obtain it, as it is very rarely required even for law professorships in the United States. However, if you must obtain a Ph.D.-level degree in order to become a professor or for other professional reasons, this is the degree for you." For example, the SJD program in UCLA had only recently been created in the new millennium. Around the time when the lead author was a graduate law student in 1990's, about 30 law schools have offered the program, which were prominent with respect to the university as a whole and the prestige of law school. Now more than 50 law schools boast of their SJD program that became more popular through the Wake Forest, Pace and Case Western. Still the University of Texas-Austin had no ads about the SJD program. Therefore, the consulting-based ranking of SJD program in the Table A1 would not be available in some cases or sharp against the usual law school rankings.

${ }^{13}$ In terms of research methodology, the research on law subject or law schools as a whole (as referred to the QS/USWR ranking in Table A1) could be more easily quantifiable (for example, undergraduate GPAs or faculty and student ratio), which is less pertinent to assess the nature and quality of graduate laws, especially for the SJD programs. The qualitative inquiry could reveal more than the quantitative method in the case of graduate laws and, in a sense, can be the proper mode to understand them. In this respect, it may be a good practice that the quotes of previous SJD students are provided by Washington University in Saint Louis in its school webpage.

${ }^{14}$ The website provides, "As a service to the International Law community, AUAP establishes... this classification. based on the program quality, admissions rate, world image of the university, average starting salary and satisfaction index of international students. This classification is global and does not reflect the comparative strength of each program in a specific field of Law (such as the international civil law, taxation, Internet, intellectual property etc.)."
} 


\section{Analysis and Implications}

Table A1 and Table A2 include the key findings of this research that show the final ranking as compared to other sources of law school ranking as well as the share of faculty with graduate law degrees compared to the whole of the APEs. As shown, the results, to an extent, corroborate with others on the general nature of law school rankings, but also differs with respect to the contingencies of each law school. The results, therefore, imply that the graduate laws need to be viewed as distinct, in which the job placement rate and research impact are a more significant indicator for the mind of graduates. The research impact of faculty is often used to assess the strength of programs or institutions, but this study rather focused on the degree holders. The rationale is that the graduate law students generally could be considered quasi-scholars so as to be more precisely rated in same way related to the faculty themselves. They also are not soinsignificant that the share of representation is less minimal than as shown in Table A2. This finding is against the general presumption that the programs are exclusively for the foreign lawyers who will return to their home countries upon graduation.

As appears in the Table A3, NYU and Georgetown had the most sizable LLM class while Yale, Lewis \& Clark $^{15}$ and Wisconsin had the smallest classes. Most law schools received 50 - 80 students yearly. The table shows that the class size is relevant to the production of law faculty as seen in the larger numbers in Columbia, NYU and Georgetown. However, Harvard excelled those schools producing 256 law faculty, although it had roughly half of those schools in terms of the total number of graduates. Yale produced around 121 law professors despite relatively small class size. Yale topped this variable, which would possibly influence the focus of other schools on legal academia, for example, UW-Madison, which also scored well in this category, ranking $2^{\text {nd }}$ behind Yale. In a sense, the graduates and programmatic designers of these schools are likely to have more of an interest and focus on the prospect of academia in terms of career management and student selection policies. These could be compared with Harvard, Columbia, NYU, and Georgetown, where the graduates also hope to be able to land lucrative high profile law jobs besides their prospects of securing a teaching position. In either case, the statistics generally show the high impact of two most prestigious law schools on the US jurisprudence and legal teaching market. As we see, contemporary jurisprudence has a temperament of one of three groups in terms of scholarly vogue and elaboration, what may be classified as the law and economics, technology and critical legal studies groups-which serve as a kind of legal monitors of modern capitalism. The first two relate to the essentials of current capitalist production and the third would be either an antithesis or a category of American realism to expose negative or problematic judicial boundedness. Richard Posner and Mark Lemley would be a notable example for the first two and Catherine Mackinnon, Richard Delgado or Kimberle Crenshaw could be in the third group. As an approach to determine the importance of research to a law school system, the legal philosophy that breeds a particular kind of

\footnotetext{
${ }^{15}$ The class size of Lewis Clark had not been presented here, but the number of faculty representation as well as citations is shown in the Appendix.
} 
scholar could be one factor that renders a school program like that of UW-Madison a possible modality to inspire other law schools ${ }^{16}$.

As you see in Table A4, that the graduate laws of Oxford have fared better than those of Cambridge corroborates our general recognition of a distinction between the humanity or social science and natural science modalities. Two schools also serving as the destination of Rhode scholars and enjoying the top caliber US college graduates, who are often related with their JDs, are Harvard and Yale. The British scholars are no less pertinent to the findings of this study. Nevertheless, they highly tend to focus on the subject of international law or social philosophy, which contrasts somewhat with the US-based national legal scholars, whose productivity and impact largely comes within the constitutional, criminal or criminal procedure, administrative and civil law field areas. The distinction also is a factor determining the research impact of British scholars, which had been represented by a relatively small number in Shapiro's aforementioned article. Interestingly, Cornell and UCLA turned out to have a small share of faculty and consequently produced less citations, although they are considered leading law schools. Ironically, however, the Cornell LLM program, for most of the relevant years, had been rated a top school globally ahead of Harvard and Yale by AUAP ${ }^{17}$. UCLA law school, with four law faculty, has also consistently been rated around $15^{\text {th }}$ amongst 200 US law schools, which makes the result a little surprising. However, the LLM graduates of both law schools appear to prefer obtaining a prestigious law job with a high salary or alternatively to work as a law professor back home (2012 Rankings of American LLM). A similar context of low research performance can be found in this study at USC and Washington University in Saint Louis. However, the latter boasts of a 97 percent success rate for students landing a job upon graduation according to its webpage. Vanderbilt, UNC, Boston College, University of Minnesota, University of Iowa, Ohio State, College of William and Mary, UC-Irvine, UC-Hastings and other similarly ranked law schools also are internationally and regionally prominent with respect to the employment of graduates, and are steady with respect to their educational mission, although not visible here in the paper.

Therefore, this study is indicative, but not an absolute measure of performance since the preferences of graduates are not all inclusive and performance measures can be diverse. For example, Ruthann Robson, a Berkeley LLM graduate and professor of CUNY, was acclaimed as a best law professor in the nation by Harvard, which is squarely within the expected role of a law professor. She also is a very competent researcher with approximately 1000 citations, but could not be so acclaimed if purely measured on the basis of her numbers and research impact. Other high ranked law schools showed good numbers as indicated by Table A5. Berkeley yielded 22 law professors with 20,996 citations in total, and Stanford was represented by 34 law professors

\footnotetext{
${ }^{16}$ As stated, the school showed strength with a high ratio of faculty to the production of graduates. This is indebted to the LLMs of Hastie fellowship, that is despite the considerable number of non-Hastie LLMs and SJDs. Beyond the aspect of program design, its Hastie fellowship program can have a precious purpose if law envisages the protection of minorities and promotion of social justice.

${ }^{17}$ Supra note 14 .
} 
with 32,260 citations in total. The graduate law ranking in this study reported that Berkeley rounded out at $12^{\text {th }}$ overall and Stanford at $6^{\text {th }}$. The reputation of subject ranking by USWR is more than significant in some cases, such as Temple law school's LLM in trial advocacy, which performed highly with the production of 58 law faculty and 11,194 citations. This is comparable with the LLM in taxations of NYU. Temple University is ranked around $50^{\text {th }}$ in the USWR law school assessment, but found at $15^{\text {th }}$ for the assessment of graduate law program in this study. This implies that the specialization effort of law schools can have much more say to produce the quality LLMs than a 3.5 undergraduate GPA of the JD entering class.

The law schools of Midwestern region or Committee of Institutional Cooperation (CIC) schools fared well, and Illinois, Michigan, Chicago and Wisconsin were rated highly. That appears because these law schools have a strong research tradition university-wide and inherent passion in the region for academics. As has been introduced, this study is an all-time conceptualization as a kind of semi-Shapiro's. However, the earliness of university education could have some impact, but seems not definitive since Stanford already yielded LLMs and JSDs in the 1960s, which is the temporal foundation of this study. The region usually would be considered a rust belt in terms of econo-political transformation, and its impact on academia would not be minimal ${ }^{18}$. But the prospect is not entirely gloomy if the academia would have a lagged impact as we see in the cases of Oxford and Cambridge at the global rating, which are the universities of past global hegemony ${ }^{19}$. Furthermore, the promise of redevelopment for the rust belt is often a top list for the presidential election. Given that the econo-political impact on the culture, intelligence and public education is not definitive, the strategy of each university and law schools in the region would be a more probable factor to address the challenges that they face, especially with respect to the quality of graduate law programs. Actually, the current trend of US college graduates shows a likely preference for medical schools or PhDs than JDs, which threatens the traditional business of law school administrators. The highly ranked law schools may not be affected, but those of upper-middle and middle range are pressed for a new response against the diminished number of applicants. Low ranked law schools may have to redefine their prospects with a new rationalization and inputs of professors or investment. Hence, the strategic aspect of school administration cannot be minimized merely because of the public esteem and dignity of legal education. It is needless to mention its importance when considering the educational effect of graduate laws programs.

\footnotetext{
${ }^{18}$ For example, UW-Madison law school was ranked around $19^{\text {th }}$ nationally in the early 1990 's, but now $33^{\text {rd }}$ in 2016 USWR.

${ }^{19}$ As stated, many interested intellectuals perceive that the international rating of global universities and other educational performance could be hyped in support of the globalization thesis. The thesis also supports the need of global capitalism for any market expansion. On the other hand, it is one lesson that the classic theory of liberal economy culminates with a monopoly in the end. In a sense, the matter also may be cultural and political beyond the economics or liberal market and besides the indicators used if the QS, THE, ARWU, US global and national rating produce a separate top-no monopoly in other words-for any check and balances as well as other implications. The knowledge economy, in this aspect, would have a multifaceted character, say, economic, social, cultural and even political as we see in the names of UNESCO and UN.
} 
Another noteworthy finding is that Yale has recently created a law $\mathrm{PhD}$ program besides the traditional research doctorate, JSD, which perhaps is similar to the $\mathrm{PhD}$ in Asian law provided by the University of Washington ${ }^{20}$. The title of $\mathrm{PhD}$ is more significant if we examine the astronomical number of citations from the economics or biological PhDs and the journals of other discipline, such as Physical Letters or IEES. Three recent graduates of Yale law $\mathrm{PhD}$ successfully landed law professorships in the job market this year, which could be a variable in the future to test the mode of graduate law in terms of scholarly productivity (Brian Leiter's, 2106). Of course, they were not included in this study since its scope is restricted to professors with years of engagement. The University of Washington, however, does not seem to reap much in this regard despite the degree name since the $\mathrm{PhDs}$ majoring in Asian law are less significant than other areas of legal topic. However, we can find a good society of Asian law research in Lung-chu Chen who has been active in New York Law School with nearly 2000 citations and collaborated with his eminent peers, such as MacDougal. In this context, the general prestige also visibly matters to a graduate's profile. Other strong law schools produce good professors with the LLM and SJD background, such as Northwestern, George Washington, Duke and Boston Universities, and University of Texas-Austin. The general law school rankings can be said less relevant at the University of Florida, which is relatively low in the law school ranking and is represented with 26 professors, but is above the University of Chicago and University of Berkeley in this variable. Nevertheless, the citations of Florida are more than small with 2121 , which comes in some contrast with those of traditionally strong law schools.

We often assume that LLMs or SJDs are for foreign attorneys who wish to learn about US laws and related specialized subjects. The ads and websites of law schools for their graduate law programs also express a penchant for the attraction of foreign attorneys. Duke, for example, so introduced its graduate law program, which may possibly create a misunderstanding if it is presumed to be exclusively for foreign lawyers. However, the study found good results at Duke, and a considerable number of Duke LLMs native of the US currently work as law professors. The citations of Duke amounted to 5272. Another interesting finding is that the LLMs of the US Military's Judge Advocate School of Law are represented more than some law schools with 13 law professors, but with a relatively small number of citations, totaling around 1348. John Marshall law school, a relatively low ranked law school boasts approximately 10,000 citations, which is a significant number. This is due in no small part to one productive scholar, and shows an important relevance of the popular approach in library science entitled "most cited" legal scholars, law review articles, and "most cited" journals of other disciplines. Most LLMs and SJDs perform better or comparably with the JD professors without an LLM degree. Assuming that, on average, the citations of a normal professor range around 150 - 300, the numbers are comparable with the professors of other back-

${ }^{20}$ The two schools are unique in conferring the $\mathrm{PhD}$ in law degree in the United States although the dual degree in collaboration with other departments, e.g., JD/PhD, is not unusual in the business of law schools. 
grounds, such as JDs without an LLM degree. The most notable dual degree form was found to be $\mathrm{JD} / \mathrm{PhDs}$ as expected-though not presented in this study. The reason for this mix is indicated to be a preference of students for exposure to the different modes of study between the taught-based and research-based degrees, and seems to reflect on the interdisciplinary context of legal research. Another reason seems to lie in the convenience that the mix would be popular or even commercialized as a set in American graduate education, as we also see in the case of $\mathrm{MD} / \mathrm{PhDs}$.

As visible in Table A2, LLM or SJD graduates are not negligible among the whole class of APEs. In proportionality with the number of graduates from both programs, say, JD's and graduate law, their share is not grossly disparate. This indicates that the law graduates consider the graduate law degree not mere ornamental, but a chance to deepen their legal knowledge as career legal educators (Cf. Sheldon \& Krieger, 2007). Nevertheless, the vein of legal academia in the US is still steered and dominated by JD degree holders, who often are great scholars of basic legal subjects, such as the constitutional and criminal laws, criminal procedure, administrative laws, torts and contractsa kind of Napoleonic rubric of modern laws and obviously the first year courses of law schools ${ }^{21}$. LLM study seems to be a significant entry point of scholarship because of its specialization, and SJD degree can be a strong stimulus to accelerate scholarly devotion in other cases $^{22}$. Such specialized study also bears relevance to address the needs of a scholar on his or her interdisciplinary conceptualization of research themes, such as law and economics ${ }^{23}$. Added to these factors inherent in the graduate law study is the finding that about all LLM degree holders had experienced the basic legal education of US law schools, while some of SJDs have no US law degree, but only LLBs of foreign law department or law schools ${ }^{24}$.

The distribution of faculty and citations had been tabulated specifically according to

\footnotetext{
${ }^{21}$ This summer, Marc D. Falkoff, a professor of Northern Illinois law school visited South Korea and presented the theme of legal education in the US. He described the three years of law school as felt by the typical student essentially as follows, "The first year is all the time that is available to learn the essential law... the second year of law school feels like a time for students to collaborate with their professors, and the third year is a period of waiting for completion and their employment prospects. This implies the importance for the first year courses in terms of learning the law".

${ }^{22}$ Once the lead author ranked the consulting-based ranking of SJD programs with much emphasis on the degree-based research impact. The high percentage of 55, as compared with the relatively small percentage of general reputation including the rank of law school's law review, faculty productivity or citations and so, was due to the fact that the graduate law degree implicates a quasi-status and character for scholars and their time is important to prepare themselves as independent researchers. One other consideration is that the doctoral degree is more durable than that of bachelor or master through the course of life-time career years, and should be consistent with "the benefit principle" or the "cost allocated to the benefit" principle. In other words, degree-based impact as a quasi-scholar or professor could be more "weightily translated" as the ranking indicator while the faculty impact "directly reflects" the productivity of each professor.

${ }^{23}$ In this area, a palpable trend is notable with combined degree holders. The trend can penetrate professors of economics $\mathrm{PhD}$ and SJD, as is the case with L. A. Bebchuk and his peers at University of Tel Aviv.

${ }^{24}$ One example would be S. J. Cho, a full time faculty at the Chicago and Kent, who is interestingly a scholar of Korean origin. He is a high impact scholar in this study with around 2000 citations, and has an LLB (JD equivalent) and MPA degrees from Seoul National University (his home country) as well as SJD from Harvard. His case also could support the conclusion that his study and successful completion of SJD degree stimulated his scholarly path, if without a JD degree.
} 
the rank of law schools except for the Extra group, and within six categories ${ }^{25}$. As appears in Table A5, it is manifest that the law faculty of the top percentile, about thirty law schools in this study, produced many more citations than those of other percentiles. The implication is that the scholarship of LLM or SJD professors can be affected by the law schools they serve. Another significant finding is the importance of leadership within the scholarly community and professional communication through law reviews, which as we see in Shapiro's most cited legal scholars and text writer categories, are strong factors to determine the research impact of LLMs and SJDs as a whole. This correlative accords with previous studies based on review of Shapiro's three articles. The numbers of "most cited" law review articles also come very close to being determinative in accounting for the whole of citations by the same authors. In other words, citations of one most cited law review article possibly can excel the whole number of other articles of respective author and well over that of other authors. The citations from "most cited scholars" can even be ten or over twenty thousands, and the citations of top percentile law schools account to three times higher than other percentile law schools. This never means that the whole range of investigation would be meaningless. Provided that 100 or 200 citations indicates a good performance for law professors, we can confidently assert that 500 - 1000 citations should be interpreted as leaving a remarkable footprint in US jurisprudence. These numbers are steady and good indicators of the product of many law professors who are unlisted in the Shapiro's "most cited" category. A final ranking, as shown Table A1, has been produced for the least number, averaged with the rank of four variables-per capita production of law faculty (representations), whole citations, per capita citations of faculty, and per capita citations of graduates. In the Appendix, you can refer to the statistics in details. Besides the final ranking in Table A1, Table A2 informs on the share of faculty with the graduate law degree holders among the total APEs, and Table A3 shows each school's number of yearly graduates and faculty representation. Table A4 includes the analyzed result of four variables with rankings. The Table A5 presents the detailed distribution of each school. Table A6 shows the faculty and total citations of global law schools or departments that have more than five representations. The Table A7 has penetrated all the remaining, whose schools at least have one faculty representation in US law schools. As shown in Table A6 and Table A7, we still can see a gap between the Latin community with the English-style alphabets and Asian nations. History and culture also can be a factor with respect to graduate law scholars of European and Latin American origin who are serving in US law schools, although in the least numbers.

\section{Conclusion}

Through the investigation, we have learned that a knowledge economy (savoir-faire) has entwined law and the actions of people in society, and growingly became edged to

${ }^{25}$ The Extra category had been arranged with around 15 mostly modest and low rank of law schools. Within the fifth percentile are the University of Hawaii, University of Maryland, Indiana University-McKinley, and one of two Penn States were included, which could possibly range around third and four percentiles. 
explain their behavior and moral and professional conduct. The growth of economy and development of technology are two essential horns leading them bullishly to a more competitive model of growth needing a constant mode of new learning. The knowledge economy has an indispensable ingredient, which is the "research" applied to each respective field, and that serves as a base or ultimate background to claim its cause for being and the participants' identities within the community. As we see, law schools sell their educational services by sporting their own libraries independent from the university-wide ones, and their compilations of books and articles compiled through heritage and history have been critical assets to reap their relatively high tuitions. On the other hand, legal education also should serve to increase practical knowledge and ability to practice law instantly upon the graduation (Edwards, 1992). This combination has been a critical dyad, long embedded on the minds and hearts of legal educators and system builders. Through this hybrid, law professors hope to find their meaning and purpose, and judges and state attorneys enjoy their social status along with their affordable salaries. It is well known that income differentials upon graduation are a component of the law school's ranking and also are predetermined in part by it. We generally do not dispute that the success of the legal education and its system are highly dependent on the research and the database they produce (Savoy, 1970). This would be a reason why almost all law schools recruit graduates with the master of library science (the other MLS than master of legal studies) degree for their library professorship. Their depository shelves are enormously stacked with scholarly sources and materials of law practice, such as federal reporters and state or regional legal documents. The authority and social interactions of law personnel are ultimately based on the research or practice products between the duality of practice and scholarship (Kennedy, 1982), and it has been hitherto unknown whether the graduate laws could perform comparably with O. W. Holmes, one of most impactful legal scholar and judge or with Richard Posner, Mark A. Lemley and C. R. Sunstein, and other most productive researchers with non-graduate laws. Is the graduate law degree merely an ornament or a dead casket found within the profiles of century old professors? Despite their relatively minority status, their share of representation within the whole faculty, their mindedness and mode of intellectual activity (i.e., more independent and subjective-yet scientific, and tending toward seminar-based learning and semi-scholarly term papers), their impact on specialization and aspects of personal stimulation through the scholarly decades, all seems still to be meaningful to the extent they impact the vestiges of scholarship. We hope that the findings and implications of this paper can help us to appreciate the nature and purpose of graduate law programs and the phenomenon of the lives and products of people relating with them (Patton, 1990; Reynolds, 2015).

Limitation in this research must be present as evidenced by the lack of prior research on this subject. Since the work is exploratory to an extent, there are many issues that need to be discussed further or refined. The expectation is that subsequent research could make this work more perfect and developed to suit the goals of legal education as well as the needs of the legal teaching market. Although it is designed to impart the sig- 
nificant impact of degree based research and the contribution of graduate versus entering professors, it's clear, for example, that publications have been curtailed under the assumption that they are produced as proportional to the number of faculty. That result could be improved with further research. This research also can be complemented with the future work, for example, dealing with a comparison between the JDs or LLBs and graduate laws.

One notes through this research that the international ranking scheme has recently grown to show the socio-culturally ubiquitous implications of the global village. The education market may likely experience a transnationalism akin to $\mathrm{McDonald}^{\circledR}$ and its presence within the global corners of neighborhoods or communities. Higher education is the most important public venue to breed leadership in each field and at each level. Educators and readers of ranking sources need to be mindful of this change, rather than focusing merely on the traditional national context of public education and consciousness. Scientific indicators and field data indicate important significance in the international dimension, which differs from the devotional loyalty or general public consciousness within the nation or local community. For example, it now has to be odd to say that Harvard or Yale and its departments are plenary to other schools or departments without any more competitive data. A contemporary understanding of social or community leadership should be different from what it was before the new millennium and the burgeoning years of new international ranking sources, such as QS and ARWU, expanding now through the Times and USWR. Without this change of mind, we may propagate an unwholesome and pernicious propaganda or quandary to inadvertently harm the development and promotion of potential national leaders or prospective national elites in various fields, such as politics, business and academic world, who, of course, are often highly educated. That is because of the substantial impact that such international dealings may have on scholarship and social and political discourse in the local context, not to mention the glocalization effect. This aspect can be further related to the increasing need for interdependence of scientific minds, the global public or open access movement of the scholarly community as well as the implications of growing competition within the knowledge economy. This paper can hopefully contribute to this area of interest with the expectation that further research will complement, critique and develop it.

\section{References}

2012 Rankings of American LL.M/Master of Law. http://www.auap.com/llm.html

Amsterdam, A. G. (1984). Clinical Legal Education-A 21st Century Perspective. Journal of Legal Education, 34, 612-618.

Black, B. S., \& Caron, P. L. (2006). Ranking Law Schools: Using SSRN to Measure Scholarly Performance. Indiana Law Journal (Symposium on The Next Generation of Law School Rankings), Vol. 81, 2006; U of Texas Law, Law and Econ Research Paper No. 52; U of Cincinnati Public Law Research Paper No. 05-14. http://ssrn.com/abstract=784764

Brian Leiter's Law School Report. http://leiterlawschool.typepad.com/

Brophy, A. L. (2015). Ranking Law Schools, 2015: Student Aptitude, Employment Outcome, and 
Law Review Citations. UNC Legal Studies Research Paper No. 2624399, 28 June 2015.

http://ssrn.com/abstract=2624399

https://doi.org/10.2139/ssrn.2624399

Creswell, J. W. (2013). Research Design: Qualitative, Quantitative, and Mixed Methods Approaches. Thousand Oaks: Sage Publications.

Edwards, H. T. (1992). The Growing Disjunction between Legal Education and the Legal Profession. Michigan Law Review, 91, 34-78. https://doi.org/10.2307/1289788

Fox, M. F. (2001). Women, Science, and Academia Graduate Education and Careers. Gender \& Society, 15, 654-666. https://doi.org/10.1177/089124301015005002

Glendon, M. A., Gordon, M. W., \& Osakwe, C. (1994). Comparative Legal Tradition: Text, Materials, and Cases on the Civil and Common Law Traditions, with Special Reference to French, German, English, and European Law. Saint Paul: West.

Kennedy, D. (1982). Legal Education and the Reproduction of Hierarchy. Journal of Legal Education, 32, 591-615.

Kim, K., Ju, H.-M., \& Khatun, M. (2015). A Teacher and Researcher: A Scratch on the Science Community and Meaning of Evaluation with the Research Doctoral Programs Ranking. International Journal of Philosophy, 3, 34-46. https://doi.org/10.11648/j.ijp.20150304.11

Korobkin, R. B. (1998). In Praise of Law School Rankings: Solutions to Coordination and Collective Action Problems. Texas Law Review, 77.

Laband, D. N. (1986). A Ranking of the Top U.S. Economics Departments by Research Productivity of Graduates. Journal of Economic Education, 17, 70-76.

Masuoka, N., Grofman, B., \& Feld, S. L. (2007). The Production and Placement of Political Science Ph.D.s, 1902-2000. PS: Political Science and Politics, 40, 361-366. https://doi.org/10.1017/S1049096507070576

McCormick, J. M., \& Bernick, E. L. (1982). Graduate Training and Productivity: A Look at Who Publishes. Journal of Politics, 44, 212-227.

Patton, M. Q. (1990). Qualitative Evaluation and Research Methods. Thousand Oaks: Sage Publications.

Pistor, K., Wellons, P. A., \& Sachs, J. (1999). The Role of Law and Legal Institutions in Asian Economic Development, 1960-1995. New York: Oxford University Press.

Priest, G. L. (1983). Social Science Theory and Legal Education: The Law School as University. Journal of Legal Education, 33, 437-441.

Reynolds, P. D. (2015). Primer in Theory Construction: An A\&B Classics Edition. London \& New York: Routledge.

Savoy, P. N. (1970). Toward a New Politics of Legal Education. The Yale Law Journal, 79, 444-504. https://doi.org/10.2307/795144

Schmidt, B. M., \& Chingos, M. M. (2007). Ranking Doctoral Programs by Placement: A New Method. PS: Political Science \& Politics, 40, 523-529. https://doi.org/10.1017/s1049096507070771

Shapiro, F. R. (2000). Most-Cited Legal Scholars. The Journal of Legal Studies, 29, 409. https://doi.org/10.1086/468080

Shapiro, F. R., \& Pearse, M. (2012). The Most-Cited Law Review Articles of All Time. Michigan Law Review, 110, 1483-1520.

Sheldon, K. M., \& Krieger, L. S. (2007). Understanding the Negative Effects of Legal Education on Law Students: A Longitudinal Test of self-Determination Theory. Personality and Social Psychology Bulletin, 33, 883-897. https://doi.org/10.1177/0146167207301014 
Sherman, L. W., \& Cohn, E. G. (1989). The Impact of Research on Legal Policy: The Minneapolis Domestic Violence Experiment. Law and Society Review, 23, 117-144. https://doi.org/10.2307/3053883

Sisk, G. C., Aggerbeck, V., Farris, N., McNevin, M., \& Pitner, M. (2015). Scholarly Impact of Law School Faculties in 2015: Updating the Leiter Score Ranking for the Top Third. 12 University of St. Thomas Law Journal 100 (2015); U of St. Thomas (Minnesota) Legal Studies Research Paper No. 15-12. http://ssrn.com/abstract=2642056 https://doi.org/10.2139/ssrn.2642056

Wizner, S. (2001). Law School Clinic: Legal Education in the Interests of Justice. Fordham Law Review, 70, 1929. 


\section{Appendix}

Table A1. The Final Ranking (Above 7 and more than 1000 citations) ${ }^{1}$.

\begin{tabular}{|c|c|c|c|c|c|}
\hline $\begin{array}{c}\text { Graduate Law } \\
\text { Ranking }\end{array}$ & Institutions & $\begin{array}{c}\text { Average } \\
\text { Column } \\
\text { (Rankings of } \\
\text { four variables } \\
\text { in the Table } \\
\text { A4 added) }\end{array}$ & $\begin{array}{c}\text { US } \\
\text { News/QS }\end{array}$ & $\begin{array}{c}\text { AUAP } \\
\text { Global LLM } \\
\text { Ranking }\end{array}$ & $\begin{array}{l}\text { Consulting-Based } \\
\text { Research Doctorate in } \\
\text { law Ranking } \\
(15 / 15 / 15 / 55)^{3}\end{array}$ \\
\hline $1^{4}(1)$ & $\begin{array}{c}\text { Univ. of } \\
\text { Wisconsin-Madison }\end{array}$ & 12 & $33 / 51-150$ & & 1 \\
\hline $2(2)$ & Yale Univ. & 14 & $1 / 4$ & 12 & 2 \\
\hline $3(3)$ & Harvard Univ. & 15 & $2 / 1$ & 5 & 3 \\
\hline 4 & Univ. of Oxford & 16 & $\mathrm{NA} / 2$ - 3 & & 5 \\
\hline $5(4)$ & $\begin{array}{c}\text { Univ. of } \\
\text { Michigan-Ann Arbor }\end{array}$ & 31 & $8 / 30-31$ & & Around 9 \\
\hline $6(5)$ & Stanford Univ. & 33 & $2 / 5-7$ & & Around 7 \\
\hline $7(6)$ & Columbia Univ. & 37 & $4 / 10-11$ & 4 & 6 \\
\hline $7(6)$ & Univ. of Virginia & 37 & $8 / 39-100$ & & Around 9 \\
\hline $9(8)$ & Univ. of Chicago & 40 & $4 / 9-15$ & 11 & 4 \\
\hline 10 & Univ. of Cambridge & 42 & $\mathrm{NA} / 2$ - 3 & & 6 \\
\hline $10(9)$ & NYU & 42 & $6 / 5$ & 3 & Around 8 \\
\hline $12(10)$ & UC-Berkeley & 44 & $8 / 9-17$ & & Around 9 \\
\hline $13(11)$ & Univ. of Illinois-UC & 49 & $40 / 151-200$ & & Around 21 \\
\hline $14(12)$ & Georgetown Univ. & 52 & $14 / 17-27$ & 20 & Around 12 \\
\hline $15(13)$ & Temple Univ. & 53 & $\begin{array}{l}\text { 50/Behind the } \\
\text { Top } 200 \mathrm{~s}\end{array}$ & & Around 31 \\
\hline $16(14)$ & George Washington Univ. & 61 & $25 / 51-150$ & & Around 15 \\
\hline $17(15)$ & Northwestern Univ. & 64 & $12 / 45-100$ & & Around 11 \\
\hline $18(16)$ & Duke Univ. & 70 & $11 / 39-47$ & 8 & Around 10 \\
\hline $19(17)$ & US Military & 72 & NA/NA & & Not Pertinent ${ }^{5}$ \\
\hline $20(18)$ & Univ. of Florida & 78 & $48 / 101-200$ & & Around 32 \\
\hline $21(19)$ & $\begin{array}{l}\text { SMU (Southern } \\
\text { Methodist) }\end{array}$ & 81 & $\begin{array}{l}\text { 45/Behind the } \\
\text { Top 200s }\end{array}$ & & Around 22 \\
\hline $22(20)$ & Univ. of Washington & 83 & $33 / 101-150$ & & Around 20 \\
\hline $23(21)$ & Univ. of Pennsylvania & 85 & $7 / 24-29$ & 2 & 6 \\
\hline $24(22)$ & Univ. of Texas-Austin & 93 & $15 / 51-100$ & & Not Pertinent \\
\hline $25(23)$ & Boston Univ. & 94 & $20 / 51-100$ & 7 & Not Pertinent \\
\hline
\end{tabular}

${ }^{1}$ The superannuated professors active with an emeritus title or other professorship in scope almost entirely were graduate law students around 1960's through 1990's. In order to understand this study in terms of a graduate law guide for the student's choice and investment decision on each school's graduate program, the temporal relevance could span from 1990 through 2020. The year of 1990 through the current would be a burgeoning or flourishing and culminating period of scholarly activity for the professors in scope, and the year of 2020 would be around the time of their diminished impact. The data compiled in this paper should be read as set for the time of late July, 2016, meaning that they constantly are changing and augmenting. ${ }^{2}$ The QS ranking has been proximate through four years of its production (2013-2016) for a law subject ranking. ${ }^{3}$ You may refer to the ranking at DOI: $10.11648 / j . i j p .20150304 .11$. ${ }^{4}$ The rank is global while the rank in parenthesis is national. " $" N o t$ Pertinent" means that the school does not offer the SJD program in any official manner. 
Table A2. Status Table I.

\begin{tabular}{cc}
\hline Total of APEs within the Law School & Around 6000 \\
\hline Faculty with the Graduate Law Degrees & $\begin{array}{c}1371 \text { (Excluding the U of London, Paris and the } \\
\text { rest of law schools) }\end{array}$ \\
Ratio & 0.2285 \\
\hline
\end{tabular}

Table A3. Status Table II (Alphabetical Order/Above 7 and more than 1000 citations).

\begin{tabular}{|c|c|c|}
\hline 25 Institutions & Graduates Yearly & $\begin{array}{c}\text { Faculty Representations } \\
\text { (=Number of faculty with the } \\
\text { graduate law degree from each } \\
\text { institution) }\end{array}$ \\
\hline Boston & 100 & 9 \\
\hline Columbia & 218 & 125 \\
\hline Duke & 78 & 15 \\
\hline Georgetown & 456 & 168 \\
\hline George Washington & 305 & 40 \\
\hline Harvard & 185 & 256 \\
\hline NYU & 445 & 230 \\
\hline Northwestern & 95 & 19 \\
\hline SMU & 30 & 7 \\
\hline Stanford & 85 & 34 \\
\hline Temple & 49 & 58 \\
\hline UC-Berkeley & 85 & 22 \\
\hline U. Cambridge & 159 & 31 \\
\hline U. Chicago & 85 & 13 \\
\hline U. Florida & 65 & 26 \\
\hline U. Illinois & 76 & 26 \\
\hline U. Michigan & 35 & 39 \\
\hline U. Oxford & 55 & 25 \\
\hline U. Penn & 123 & 11 \\
\hline U. Texas & 60 & 8 \\
\hline U. Virginia & 55 & 39 \\
\hline U. Washington & 80 & 9 \\
\hline U. Wisconsin & 15 & 40 \\
\hline US Military & 20 & 13 \\
\hline Yale & 30 & 121 \\
\hline
\end{tabular}


Table A4. Analysis Table (Alphabetical Order/Above 7 and more than 1000 citations) ${ }^{1}$.

\begin{tabular}{|c|c|c|c|c|}
\hline 25 Institutions & Total Citations & Rep./Graduates & Citations/Rep. & Citations/Graduates \\
\hline Boston & $1267(23)$ & $0.09(24)$ & $140.77(22)$ & $12.67(25)$ \\
\hline Columbia & $60,338(5)$ & $0.57(8)$ & $482.70(13)$ & $276.77(9)$ \\
\hline Duke & $5272(18)$ & $0.19(18)$ & $351.47(16)$ & $67.59(18)$ \\
\hline Georgetown & $48,134(7)$ & $0.37(13)$ & $286.51(17)$ & $105.56(15)$ \\
\hline $\begin{array}{c}\text { George } \\
\text { Washington }\end{array}$ & $24,825(12)$ & $0.13(21)$ & $620.63(11)$ & 81.39 (17) \\
\hline Harvard & $228,863(1)$ & $1.38(3)$ & $894.00(7)$ & $1237.10(4)$ \\
\hline NYU & $80,984(4)$ & $0.52(9)$ & $352.10(15)$ & $181.99(14)$ \\
\hline Northwestern & $8080(17)$ & $0.2(17)$ & $425.26(14)$ & $85.05(16)$ \\
\hline SMU & $1057(24)$ & $0.23(16)$ & $151(21)$ & $35.23(20)$ \\
\hline Stanford & $32,260(9)$ & $0.40(11)$ & $948.82(6)$ & $379.53(7)$ \\
\hline Temple & $11,194(16)$ & $1.18(4)$ & $193(20)$ & $228.45(13)$ \\
\hline UC-Berkeley & $20,996(14)$ & $0.26(15)$ & $954.36(5)$ & $247.01(10)$ \\
\hline U Cambridge & $37,057(8)$ & $0.19(18)$ & $1195.38(4)$ & $233.06(12)$ \\
\hline U Chicago & $30,398(10)$ & $0.15(20)$ & $2338.31(2)$ & $357.62(8)$ \\
\hline U Florida & $2121(21)$ & $0.40(11)$ & $81.58(25)$ & $32.63(21)$ \\
\hline U Illinois & $18,317(15)$ & $0.34(14)$ & $704.5(9)$ & $241.01(11)$ \\
\hline U Michigan & $26,238(11)$ & $1.11(5)$ & $672.77(10)$ & $749.66(5)$ \\
\hline U Oxford & $90,219(2)$ & $0.45(10)$ & $3608.76(1)$ & $1640.35(3)$ \\
\hline U Penn & $2676(19)$ & $0.09(24)$ & 243.27 (19) & $21.76(23)$ \\
\hline U Texas & $1055(25)$ & $0.13(21)$ & $131.88(23)$ & $17.58(24)$ \\
\hline U Virginia & $22,990(13)$ & $0.71(6)$ & $589.49(12)$ & $418(6)$ \\
\hline U WA & $2245(20)$ & $0.11(23)$ & $249.44(18)$ & $28.06(22)$ \\
\hline U Wisconsin & $52,023(6)$ & $2.66(2)$ & $1300.58(3)$ & $3468.2(1)$ \\
\hline US Military & $1348(22)$ & $0.65(7)$ & $103.69(24)$ & $67.4(19)$ \\
\hline Yale & 86,667 (3) & $4.03(1)$ & $716.26(8)$ & $2888.9(2)$ \\
\hline
\end{tabular}

${ }^{1}$ The number in parenthesis indicates a rank among 25 institutions. The Table A4 includes four variables (total citation/per capita faculty production/per faculty citation/per graduate citation) to yield a final ranking in Table A1. 
Table A5. Distribution chart of LLM/SJD/PhD in law-alphabetical order and above $8^{1}$.

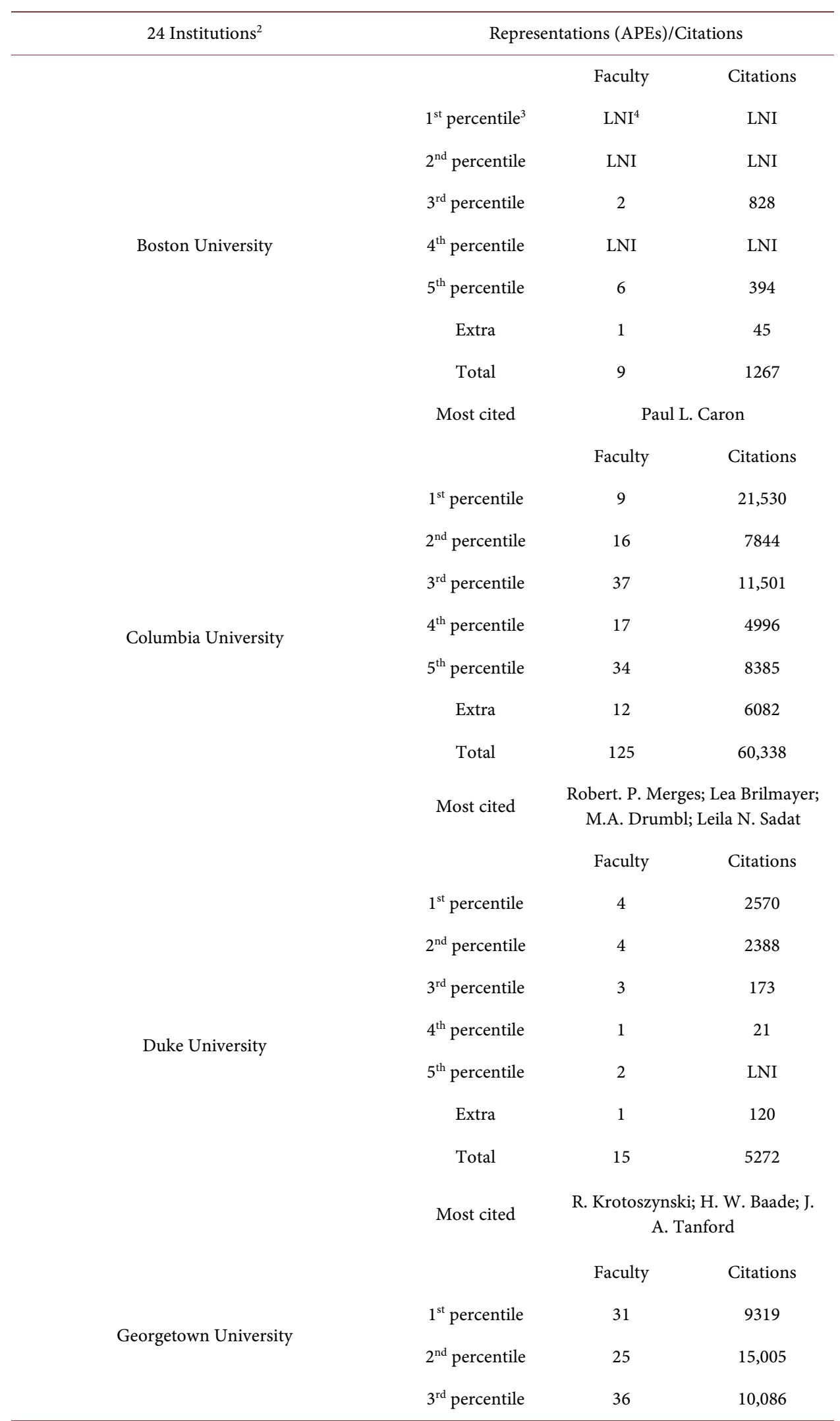




\section{Continued}

George Washington University

Harvard University

New York University

$\begin{array}{ccc}4^{\text {th }} \text { percentile } & 19 & 3645 \\ 5^{\text {th }} \text { percentile } & 49 & 6982 \\ \text { Extra } & 8 & 3097 \\ \text { Total } & 168 & 48,134\end{array}$

D. A. Harris; J. A. Barron; J. G.

Most cited Hodge; J. Dunoff; N. R. Cahn; A. Camacho

$$
\text { Faculty Citations }
$$

$1^{\text {st }}$ percentile

$2^{\text {nd }}$ percentile

$3^{\text {rd }}$ percentile

$4^{\text {th }}$ percentile

$5^{\text {th }}$ percentile

Extra

Total

Most cited

$1^{\text {st }}$ percentile

$2^{\text {nd }}$ percentile

$3^{\text {rd }}$ percentile

$4^{\text {th }}$ percentile

$5^{\text {th }}$ percentile

Extra

Total

Most cited

$1^{\text {st }}$ percentile

$2^{\text {nd }}$ percentile

$3^{\text {rd }}$ percentile

$4^{\text {th }}$ percentile

$5^{\text {th }}$ percentile

\section{3}

4005

1200

5177

3689

10,174

580

24,825

M. Cherif Bassiouni; Michael Blumm; J. B. Ruhl; S. L. Schooner

$$
\text { Faculty Citations }
$$

66

144,000

35

17,803

53

26,343

27

10,273

53

14,614

22

15,830

256

228,863

Robert Howse; L. A. Bebchuk; Paul Robinson; H. P. Monaghan; M. J. Matsuda; M. Wyman; Lynn M. Lopucki; M. S. Moore; Richard W. Wright

$$
\text { Faculty Citations }
$$

$31 \quad 46,979$

34

8242

45

6542

27

3996

63

6625 
K. Kim et al.

\section{Continued}

Northwestern University

Extra

Total

Most cited

Stanford University

Temple University

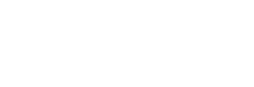

Extra

Total

Most cited

Most cited

$5^{\text {th }}$ percentile
Extra
Total

\section{John C. Coffee; Peter H. Schuck; L. C. McClain; B. E. Hernandez; Susan Daicoff}

$$
\text { Faculty Citations }
$$

$1^{\text {st }}$ percentile

$2^{\text {nd }}$ percentile

$3^{\text {rd }}$ percentile

$4^{\text {th }}$ percentile

$5^{\text {th }}$ percentile

$1^{\text {st }}$ percentile

$2^{\text {nd }}$ percentile

$3^{\text {rd }}$ percentile

$4^{\text {th }}$ percentile

$5^{\text {th }}$ percentile

$1^{\text {st }}$ percentile

$2^{\text {nd }}$ percentile

$3^{\text {rd }}$ percentile

$4^{\text {th }}$ percentile

$5^{\text {th }}$ percentile

Extra

Total

Most cited
1

20

\section{1}

\section{8}

1

\section{6}

2

2

19

V. P. Nanda; F. Teson; Lung-chu Chen

$\begin{array}{cc}\text { Faculty } & \text { Citations } \\ 5 & 19,608 \\ 7 & 3631 \\ 5 & 4118 \\ 3 & 2170 \\ 14 & 2733 \\ \text { LNI } & \\ 34 & 32,260\end{array}$

Neil W. Netanel; Robin West; Dan L. Burk; Ted Schneyer; F. Valdes faculty Citations LNI LNI

$1 \quad 180$

$13 \quad 3375$

$13 \quad 3435$

$25 \quad 3314$

$6 \quad 890$

$58 \quad 11,194$

E. S. Podgor; R. K. Neumann; Llewellyn J. Gibbons 


\section{Continued}

University of California-Berkeley

University of Cambridge

University of Chicago

University of Florida

Faculty

Citations

$1^{\text {st }}$ percentile

$2^{\text {nd }}$ percentile

$3^{\text {rd }}$ percentile

$4^{\text {th }}$ percentile

$5^{\text {th }}$ percentile

Extra

Total

Most cited

$1^{\text {st }}$ percentile

$2^{\text {nd }}$ percentile

$3^{\text {rd }}$ percentile

$4^{\text {th }}$ percentile

$5^{\text {th }}$ percentile

Extra

Total

Most cited

$1^{\text {st }}$ percentile

$2^{\text {nd }}$ percentile

$3^{\text {rd }}$ percentile

$4^{\text {th }}$ percentile

$5^{\text {th }}$ percentile

Extra

Total

Most cited 
K. Kim et al.

\section{Continued}

University of Illinois

$3^{\text {rd }}$ percentile
$4^{\text {th }}$ percentile
$5^{\text {th }}$ percentile
Extra
Total

5

1312

Most cited

G. L. Germain

$$
\text { (1) }
$$

$1^{\text {st }}$ percentile

Faculty

Citations

$2^{\text {nd }}$ percentile

3

3500

$3^{\text {rd }}$ percentile

$4^{\text {th }}$ percentile

$5^{\text {th }}$ percentile

Extra

Total

Most cited

University of Michigan

University of Oxford

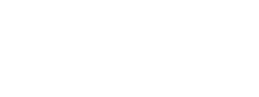




\section{Continued}

University of Pennsylvania

University of Texas

University of Virginia

University of Washington

Joseph Raz; John Finnis; Jeremy

Waldron; Benedict Kingsbury;

Most cited

Stephanos Bibas; MW Janis; RN

Gardner

\section{Faculty Citations}

$1^{\text {st }}$ percentile

1

120

$2^{\text {nd }}$ percentile

$3^{\text {rd }}$ percentile

$4^{\text {th }}$ percentile

$5^{\text {th }}$ percentile

Extra

Total

Most cited

$2^{\text {nd }}$ percentile

$3^{\text {rd }}$ percentile

$4^{\text {th }}$ percentile

$5^{\text {th }}$ percentile

Extra

Total

Most Cited

$1^{\text {st }}$ percentile

$2^{\text {nd }}$ percentile

$3^{\text {rd }}$ percentile

$4^{\text {th }}$ percentile

$5^{\text {th }}$ percentile

Extra

Total

Most cited 
K. Kim et al.

\section{Continued}

University of Wisconsin

US Military (Judge Advocate)

Yale University

$\begin{array}{ccc}3^{\text {rd }} \text { percentile } & \text { LNI } & \text { LNI } \\ 4^{\text {th }} \text { percentile } & 2 & \text { LNI } \\ 5^{\text {th }} \text { percentile } & 3 & 45 \\ \text { Extra } & \text { LNI } & \text { LNI } \\ \text { Total } & 9 & 2245\end{array}$

Most cited

John O Haley; Toshiko Takenaka

$1^{\text {st }}$ percentile

$2^{\text {nd }}$ percentile

$3^{\text {rd }}$ percentile

$4^{\text {th }}$ percentile

$5^{\text {th }}$ percentile

Extra

Total

Most cited

W. LaFave; Kimberle Crenshaw; Catherine Fisk; M. Goodwin; Jan G. Laitos

Faculty

Citations

$1^{\text {st }}$ percentile

$2^{\text {nd }}$ percentile

$3^{\text {rd }}$ percentile

$4^{\text {th }}$ percentile

$5^{\text {th }}$ percentile

Extra

Total

Most cited

E. Talbot Jensen; Eugene

R. Milhizer

Faculty

Citations

$1^{\text {st }}$ percentile

31

44,493

$2^{\text {nd }}$ percentile

15

3194

$3^{\text {rd }}$ percentile

20

2531

$4^{\text {th }}$ percentile 


\section{Continued}

$\begin{array}{ccc}5^{\text {th }} \text { percentile } & 32 & 18,699 \\ \text { Extra } & 13 & 9172 \\ \text { Total } & 121 & 86,667 \\ & \text { W. Michael Reisman; Gideon } \\ \text { Most cited } & \begin{array}{l}\text { Parchomovsky; L. L. Riskin; } \\ \text { Chinkin Crhristine; Henry } \\ \end{array} & \begin{array}{l}\text { Manne; L. Brickman } \\ \text { Mand }\end{array}\end{array}$

${ }^{1}$ The listing was made in alphabetical order of school name. "Most cited" below had not been made of order that does not indicate more counts or comparison with other schools. The names had been cursorily selected that just were illustrative to represent each school. ${ }^{2}$ Another institution for the final ranking is the Southern Methodist law school as listed in Table A6, and could help to complete top 25 in Table A1. ${ }^{3}$ The column represents law schools that the graduate laws are now serving, and percentiles are accorded with the USWR ranking of law schools-with a minor exception as mentioned and besides Extra. ${ }^{4} \mathrm{LNI}$ means "least in number or non-identifiable".

Table A6. Other Schools above 5 (Faculty/Citations Only) ${ }^{1}$.

\begin{tabular}{|c|c|c|}
\hline & Faculty & Citations \\
\hline University of London & 31 & 26,042 \\
\hline University of Paris & 10 & 10,510 \\
\hline John Marshall Law School & 6 & 9140 \\
\hline Lewis \& Clark & 5 & 1402 \\
\hline NIU-Ireland & 5 & 456 \\
\hline Pace U. & 6 & 1200 \\
\hline SMU & 7 & 1057 \\
\hline Tulane U. & 6 & 59 \\
\hline U. of Arkansas & 5 & 650 \\
\hline U. of Denver & 5 & 677 \\
\hline U. of Houston & 7 & 277 \\
\hline U. of Missouri & 7 & 672 \\
\hline Washington U. St. Louis & 5 & 2830 \\
\hline
\end{tabular}

${ }^{1}$ The most cited graduate law degree holders are M. Cherif Bassiouni for John Marshall Law School and George C. Thomas for the Washington University St. Louis.

- U. Paris and U. London had just been given the statistics that were excluded from the final ranking scheme since the information of status was not confirmed. The ranking would be around the mid-low $\left(15^{\text {th }}-20^{\text {th }}\right)$ if approximate and included. 
Table A7. The rest of schools (faculty representation/citations).

\begin{tabular}{|c|c|}
\hline & Result (Nothing implicated with order) \\
\hline $\begin{array}{l}\text { Schools } \\
\text { (Faculty/ } \\
\text { Citations) }\end{array}$ & 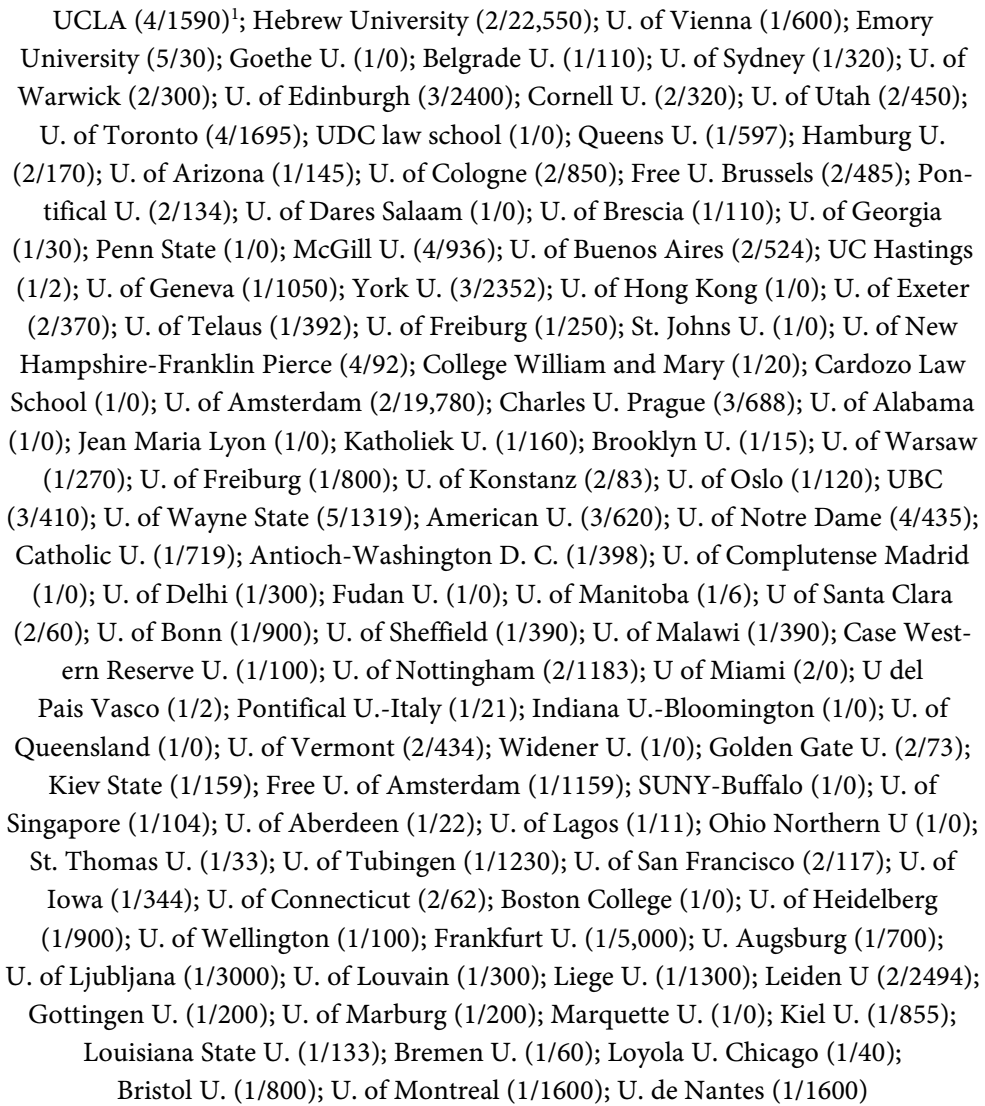 \\
\hline
\end{tabular}

The degree origin not included thus far had been distributed across the universities of European states, such as Poland (1/490), Euro Institute (2/265), Germany (1/105), Spain (3/0), Italy (1/3000), and some others in a minimal number. India (1/850) besides the Puerto Rico (2/0) also had a representation. ${ }^{1}$ The most cited graduate law degree holder is W. J. Aceves for UCLA. 
Submit or recommend next manuscript to SCIRP and we will provide best service for you:

Accepting pre-submission inquiries through Email, Facebook, LinkedIn, Twitter, etc. A wide selection of journals (inclusive of 9 subjects, more than 200 journals)

Providing 24-hour high-quality service

User-friendly online submission system

Fair and swift peer-review system

Efficient typesetting and proofreading procedure

Display of the result of downloads and visits, as well as the number of cited articles

Maximum dissemination of your research work

Submit your manuscript at: http://papersubmission.scirp.org/

Or contact blr@scirp.org 